\title{
Phytoremediation of Copper and Zinc Contaminated Soil around Textile Industries using Bryophyllum pinnatum Plant
}

\author{
Mumtahina Riza ${ }^{1 *}$, Sirajul Hoque ${ }^{2}$ \\ 1 Department of Environmental Science, Bangladesh University of Professionals, Dhaka, Bangladesh \\ 2 Department of Soil, Water and Environment, University of Dhaka, Dhaka, Bangladesh \\ * Corresponding author's email: mumtahina@seu.edu.bd
}

\begin{abstract}
Phytoremediation is an acceptable, economical, and eco-friendly way to remediate the metal contaminated soils beside the industrial zone. Like other industries, the textile industries generate the effluent containing several types of pollutants such as metal conjugated dyes, several inorganic and organic substances, etc. When discharged to the environment, metals - specifically heavy metals - exert an adverse impact on soil and other biotas through the food chain. In this study, Bryophyllum pinnatum was used for phytoremediation in the contaminated soil sample collected from the area located around textile industries in Kaliakair, Bangladesh. The experiment was carried out by ex-situ in earthen pots. The concentration of six heavy metals including $\mathrm{Zn}, \mathrm{Cu}, \mathrm{Ni}, \mathrm{Cr}, \mathrm{Pb}$, and $\mathrm{Cd}$ was analyzed before applying phytoremediation. Two heavy metals, $\mathrm{Cu}(28.57 \mu \mathrm{g} / \mathrm{g})$ and $\mathrm{Zn}(143.88 \mu \mathrm{g} / \mathrm{g})$ were found and others were not detected in that soil. After planting of Bryophyllum pinnatum, the concentrations of $\mathrm{Cu}$ and $\mathrm{Zn}$ in the contaminated soil were analyzed at three intervals of 45 days $\left(\mathrm{S}_{3}\right), 90$ days $\left(\mathrm{S}_{4}\right)$, and 135 days $\left(\mathrm{S}_{5}\right)$ in three replications. The experiment revealed that there was a decline in the concentration of $\mathrm{Cu}$ in soil $(27.08 \mu \mathrm{g} / \mathrm{g}$ for 45 days and $13.19 \mu \mathrm{g} / \mathrm{g}$ for 90 days) except for the $3^{\text {rd }}$ replication of 135 days $\left(\mathrm{S}_{5}\right)$. However, the concentration of $\mathrm{Zn}$ (mean $103.09 \mu \mathrm{g} / \mathrm{g}$ ) in soil was measured at 45 days and then remained within nearer values of concentration for other replications. The amounts of heavy metals uptake for both $\mathrm{Cu}$ and $\mathrm{Zn}$ by plants can be presented as leaves> stem $>$ root which indicated that heavy metals were transferred from root to shoot over time. Bryophyllum pinnatum can, therefore, be considered as a good hyperaccumulator plant having $\mathrm{BCF}>1$ and $\mathrm{TF}>1$ values as well as possessing a better capacity of phytoextraction of metals.
\end{abstract}

Keywords: contaminated soil, heavy metal, phytoremediation, Bryophyllum pinnatum

\section{INTRODUCTION}

Pollution of the environmental segments due to anthropogenic activities is inevitable. Different physical, chemical, and other approaches were suggested and also applied to improve the condition of the contaminated soil with mixed results. Contamination of heavy metal exposes a crucial health concern as metals might be transferred to human beings along with livestock (Dubey et al., 2018). Heavy metals such as $\mathrm{Cd}, \mathrm{Cu}, \mathrm{Pb}, \mathrm{Cr}$, and $\mathrm{Hg}$ are considered as prime contaminants in the environment, specifically, where there is a vast amount of anthropogenic load (Nagajyoti et al., 2010). The heavy metals readily found in the textile effluent are $\mathrm{As}, \mathrm{Cd}, \mathrm{Cu}, \mathrm{Fe}, \mathrm{Hg}, \mathrm{Cr}$, and $\mathrm{Ni}$
(Nagajyoti et al., 2010). Heavy metals like cadmium $(\mathrm{Cd})$, copper $(\mathrm{Cu})$, lead $(\mathrm{Pb})$, nickel $(\mathrm{Ni})$, and chromium (Cr) are extensively used for the manufacturing of textile dyes. Different heavy metals are linked with the configuration of dyes. When textile effluents arrive in the soil; there are possibilities of soil to come into contact with metal. Watering the agricultural lands by using different industrial wastewaters may alter the chemical, physical and biological properties of soil (Mani et al., 2019). $\mathrm{Cu}, \mathrm{Pb}$, and $\mathrm{Cr}$ were the prominent heavy metal from the dyeing, glass, and textile industry, at Tangail, Bangladesh (Tusher et al., 2018).

Phytoremediation refers to a combination of plant-based technologies that utilize the naturally occurring plants as well as genetically engineered 
plants for removing pollutants from environment (Prasad and De Oliveira Freitas, 2003). It is considered an environmentally friendly, appealing, soothing, non-harmful, energy-efficient, and beneficial mechanism to remediate the area with low-to-moderate intensities of heavy metal(loid) s (Sabir et al., 2015). It is based upon several methods such as phytodegradation, phytovolatilization, phytoaccumulation, and phytoextraction (Muthusaravanan et al., 2018). Cu, Zn, Cd, Ni, $\mathrm{Cr}$, and $\mathrm{Pb}$ can be accumulated by various plants like Calandulaofficinalis, Arabidopsis thaliana, Cynodondactylon, Brassica juncea, Bidenspilosa, Helianthus annuus (Alaboudi et al., 2018; Goswami and Das, 2016; Wei et al., 2018). The greatest number of plants (more than 300 species) take up $\mathrm{Zn}, \mathrm{Ni}$, and $\mathrm{Cu}$ preferably; hence, these heavy metals are the most appropriate choice for the method of phytoextraction (Gupta and Balomajumder, 2015; Muthusaravanan et al., 2018). Metal accumulator plants possess the capacity of gathering heavy metals in their tissues remaining above ground without any indication of toxicity emerging (Srivastava, 2016). The plant tissues can accumulate the existing heavy metals from the soil; moreover, these metals can gather in the trophic levels of the food web by entering the biosphere (Shah and Daverey, 2020).

Heavy metals are released into the soil and become accumulated because of the use of agricultural chemicals, municipal wastages, and contaminated industrial wastewater (Kumar et al., 2019). Indiscriminate discharge of industrial effluents, waste of mines, community litters along with heavy metal polluted sludge are the major reasons for soil contamination (Mao et al., 2015; Ye et al., 2017). Conversely, the delivery of industrial effluents helps to enrich the irrigated lands by storing nutrients for microbes (Jain et al., 2005; Li et al., 2015). Microbial diversity and their associated activities are adversely affected by the heavy metals due to contamination for a longer period (Chen et al., 2014). Toxic metals are nondegradable and accumulated in nature, as a result they consequently enter into the food chain (Patra et al., 2020). The model plant which is to be applied for improvement of heavy metal-contaminated soils needs to possess some special features like fast-growing capacity in several climatic situations and easily cultivable which facilitate the diminishing of significant quantities of toxicants (Pinto et al., 2015). For instance, N. mucronataacts as the best accumulator for several heavy metals such as $\mathrm{Pb}, \mathrm{Zn}, \mathrm{Cu}, \mathrm{Ni}$, and $\mathrm{Cd}$ (Chehregani et al., 2009). In terms of heavy metal removal, hyperaccumulator plants do not preclude the metals to reach into the roots, instead they permit the accretion of metals into the biomass of plants (Patra et al., 2020).

\section{MATERIALS AND METHODS}

\section{Study site}

The soil sample used in the study was collected from Kaliakair Upazila of Gazipur, Bangladesh. Gazipur is an industrial area with having a total area of $1,1741.53$ square kilometers and a total population of 3403912 , an annual average temperature maximum of $37^{\circ} \mathrm{C}$ and a minimum of $10{ }^{\circ} \mathrm{C}$; average rainfall of $642.06 \mathrm{~mm}$. The location of Kaliakair is specified by latitude: $24^{\circ}$ $10^{\prime} 0^{\prime \prime} \mathrm{N}$ and longitude: $90^{\circ} 10^{\prime} 0$ " $\mathrm{E}$. There are many industries established in Gazipur, such as chemicals, textile, knitting, dyeing, finishing, garments, etc.

\section{Collection of soil and plantation of Bryophyllum pinnatum in ex-situ}

The contaminated soil was collected on 17th March 2020 around Textile industries, Bangladesh (Figure 1). The soil sample weighing a total of ninety $\mathrm{kg}$ was collected randomly from nine different points at a single spot of Kalaikair from a depth of $0 \mathrm{~cm}$ to $15 \mathrm{~cm}$. An equal amount of soil was taken of the above-mentioned depth from each point of the sampling site. Finally, soils were mixed scientifically to make one composite sample. The $\mathrm{pH}$ of the soil sample was measured by a pH meter (Jenway 3305) using a 1:5 soil to water ratio. The composite soil sample was spread on a sheet of paper and the loose aggregated soil was broken gently. Then the soil sample was sun-dried for 5 days in the presence of air. The dried weight of the composite soil was approximately $50 \mathrm{~kg}$.

A total of nine earthen pots were prepared to accommodate three replications of the plantation ( 3 pots in each replica) for three different intervals of 45 days $\left(\mathrm{S}_{3}\right), 90$ days $\left(\mathrm{S}_{4}\right)$ and 135 days $\left(\mathrm{S}_{5}\right)$ in ex-situ. Each pot was filled with 5 $\mathrm{kg}$ of soil. An additional replica was made and further prepared to measure the percentage of organic matter and soil texture of contaminated 


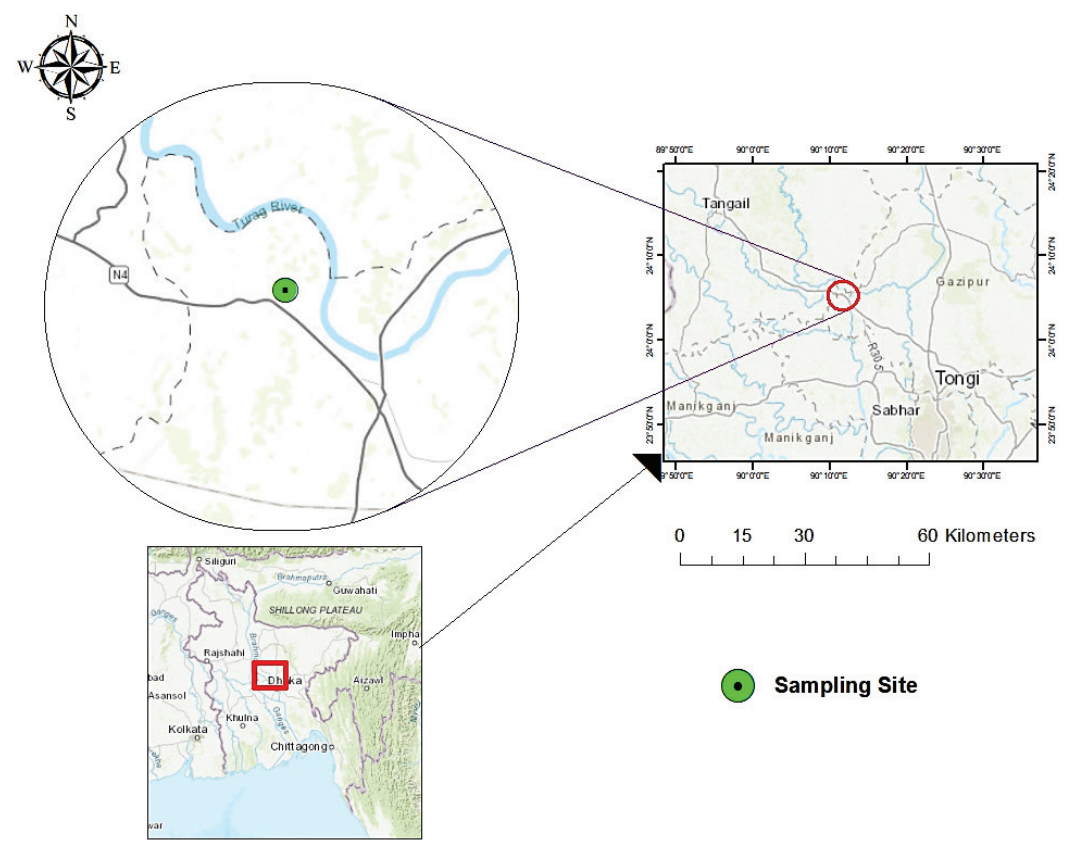

Figure 1. Soil collection site (Kaliakair, Gazipur, Bangladesh)

soil before planting seedlings. Two seedlings of Bryophyllum pinnatum (approximate age of 15 days) were planted in each earthen pot following the regular watering was done on the plants. Finally, after completion of the specific intervals, soils were collected from the earthen pot and stored in the labeled jar. A periodic analysis was performed to obtain the result of the phytoremediation of heavy metal.

\section{Sample preparation and chemical analysis of soil and plant}

The textural class of the soils was measured by using a triangular diagram following the USDA hydrometer method. The organic matter content $(\%)$ was experimented by Walkley and Black's wet oxidation method. After uprooting the plants from the different pots having various intervals (45 days, 90 days, and 135 days), the different parts of the plants such as root, stem, and leaves were separated for each replication. The plant parts were washed mildly by distilled water for about 2.5 minutes to remove the adhered soil particles from the plants. Then those plant parts were dried in the microwave oven at $80^{\circ} \mathrm{C}$ and ground by using a grinding machine to facilitate subsequent testing. The dried plant samples were filtered with a $1 \mathrm{~mm}$ sieve. The soil samples were also sieved in the same way. The respective soil and plant samples were digested using the hot-block digestion method (USEPA 3050B) for measuring the total concentration of various metals such as $\mathrm{Ni}, \mathrm{Cr}, \mathrm{Pb}, \mathrm{Cu}, \mathrm{Zn}$, and $\mathrm{Cd}$ that were analyzed by atomic absorption spectrophotometer (Varian AA240).

\section{Statistical analysis and graphical presentation}

Three replications were made and three values of metal concentrations were taken from three pots under each replication for soil, root, stem, and leaves to obtain the average value. The statistical analysis was carried out using one-way ANOVA (analysis of variance) followed at $(\mathrm{p}<0.05)$ significance level. The data summary and calculations were performed using Microsoft Excel, and the graphical representation was done using R Studio v.1.3.1093. The map of the soil collection site was made by means of ArcGIS 10.4.1 software.

\section{RESULTS AND DISCUSSION}

\section{Physicochemical properties of soil}

The observed result of $\mathrm{pH} 5.65$ indicates that the raw contaminated soil is acidic. In the case of metal cations, lower $\mathrm{pH}$ resembles the higher mobility and availability for plants (Shah and Daverey, 2020). Contrarily, at higher $\mathrm{pH}$, these ions show the tendency to be absorbed in the soil, resulting in the reduction of such movement and 
further its availability as well as this phenomenon is correct for the anions of metals (Kader et al., 2016; Shaheen et al., 2013). Tusher et al., (2017), found the value of soil $\mathrm{pH}$ of $4.4,6.1$, and 6.4 around the dyeing, glass, and textile industries respectively in Tangail, Bangladesh. A higher value of $\mathrm{pH}$ than in the present study was found from the sampling sites of Padaeng zinc mine area, Thailand within the range of 7.1-7.6 (Phaenark et al., 2009). This result indicated that the soil $\mathrm{pH}$ around industrial zone remained within the range of acidic to neutral value.

According to the soil texture triangle, the collected soil from around textile industries comprises clay, silt, and sand having an amount of $14.075 \%$, 40.375\%, and $45.55 \%$ respectively. Therefore, the soil has loamy characteristics. Herlina et al., (2020) found the properties of soil containing clay $11.67 \%$, silt $45.78 \%$, and sand $42.55 \%$. This study observed nearly similar results of the soil texture from the contaminated soil in Gedang Anak village, Ungaran Timur district Semarang, Indonesia. The texture of soil plays a crucial role in the availability of metals in the soil. For instance, the soil having fine texture holds about eight times higher quantity of heavy metal - such as $\mathrm{Pb}$ - compared to the soil having coarser texture (Sherene, 2010). Volk and Yerokun, (2016), observed the presence of 1.7 times higher bioavailable concentration of Cobalt and Chromium in clay loam soil compared to sandy loam

Table 1. Physicochemical properties of contaminated soil

\begin{tabular}{|l|c|l|}
\hline \multicolumn{1}{|c|}{ Parameters } & Value & \multicolumn{1}{c|}{ Remark } \\
\hline $\mathrm{pH}$ & 5.65 & Acidic \\
\hline Organic content (\%) & $0.11 \%$ & $\begin{array}{l}\text { Presence of a slight } \\
\text { amount of carbon }\end{array}$ \\
\hline Soil texture & $14.075 \%$ & \multirow{2}{|}{} \\
\cline { 1 - 2 } Clay & $40.375 \%$ & Loam \\
\cline { 1 - 2 } Silt & $45.55 \%$ & \\
\hline Sand &
\end{tabular}

soil while studying the route of these metals in different soil fractions.

Moreover, the amount of organic matter content (\%) in the soil of the study area around textile industries at Kaliakair, Gazipur showed the result of $0.11 \%$. This result resembles the lower organic matter content than the previously done work in Konabari, Gazipur having the range 0.6-1.19\% (Islam, 2012). The average organic matter content $(\%)$ in the soil was $6.45,4.52$, and $1.31 \%$ in surface soil around the dyeing, textile, and glass industry in Tangail, respectively (Tusher et al., 2017). Therefore, in the present study, there is a presence of a small amount of OM content in the soil around Kaliakair, Gazipur beside textile industries compared to the previous work in the Konabari and Tangail area. According to longterm fieldwork, it is observed that the addition of organic matter to soil impacts the immobilization of metal because of the holding capability $\mathrm{OM}$ and reveals the positive influences on the availability of metal (Cambier et al., 2014).

\section{Concentration of metals in the control soil and plants}

As shown in Table 2 and 3, there was presence of $\mathrm{Cu}(16.62 \mu \mathrm{g} / \mathrm{g})$ and $\mathrm{Zn}(78.06 \mu \mathrm{g} / \mathrm{g})$ in control soil. The control plants possess some amount of metals in the root, stem, and leaves already after 45 days. The reason behind this distribution of heavy metals into the different parts of the control plant from the soil might be because of the availability of some amount of metals in the soil generally.

\section{Uptake of Copper by Bryophyllum pinnatum from soil}

Figure 2 indicates that the concentration of $\mathrm{Cu}(\mu \mathrm{g} / \mathrm{g})$ in the root tends to decrease with time. However, the stem and the leaves tend to show the accumulation of $\mathrm{Cu}$ in the increasing

Table 2. Concentration of $\mathrm{Cu}$ in the control soil, contaminated soil and plants

\begin{tabular}{|c|c|c|c|c|c|c|}
\hline \multirow{2}{*}{ SI. No. } & \multirow{2}{*}{ Period (days) } & \multirow{2}{*}{ Sample ID } & \multicolumn{4}{|c|}{ Cu Concentration $(\mu \mathrm{g} / \mathrm{g})$} \\
\cline { 4 - 7 } & & & Soil & Root & Stem & Leaves \\
\hline 01 & - & $\mathrm{S}_{0}$ & 16.62 & - & - & - \\
\hline 02 & - & $\mathrm{S}_{1}$ & 28.57 & - & - & - \\
\hline 03 & 45 & $\mathrm{~S}_{2}$ & - & 40.39 & 15.1 & 10.18 \\
\hline
\end{tabular}

Note: $\mathrm{S}_{0}-$ control soil; $\mathrm{S}_{1}-$ contaminated soil; $\mathrm{S}_{2}-$ control plant (plant from uncontaminated soil). 
Table 3. Concentration of $\mathrm{Zn}$ in the control soil, contaminated soil and plants

\begin{tabular}{|c|c|c|c|c|c|c|}
\hline \multirow{2}{*}{ SI. No. } & \multirow{2}{*}{ Period (days) } & \multirow{2}{*}{ Sample ID } & \multicolumn{4}{|c|}{ Zn Concentration $(\mu \mathrm{g} / \mathrm{g})$} \\
\cline { 4 - 7 } & & & Soil & Root & Stem & Leaves \\
\hline 01 & - & $\mathrm{S}_{0}$ & 78.06 & - & - & - \\
\hline 02 & - & $\mathrm{S}_{1}$ & 143.88 & - & - & - \\
\hline 03 & 45 & $\mathrm{~S}_{2}$ & - & 385.35 & 246.91 & 102.36 \\
\hline
\end{tabular}

Note: $\mathrm{S}_{0}-$ control soil; $\mathrm{S}_{1}-$ contaminated soil; $\mathrm{S}_{2}-$ control plant (plant from uncontaminated soil).

Concentration of $\mathrm{Cu}$ in Contaminated Soil

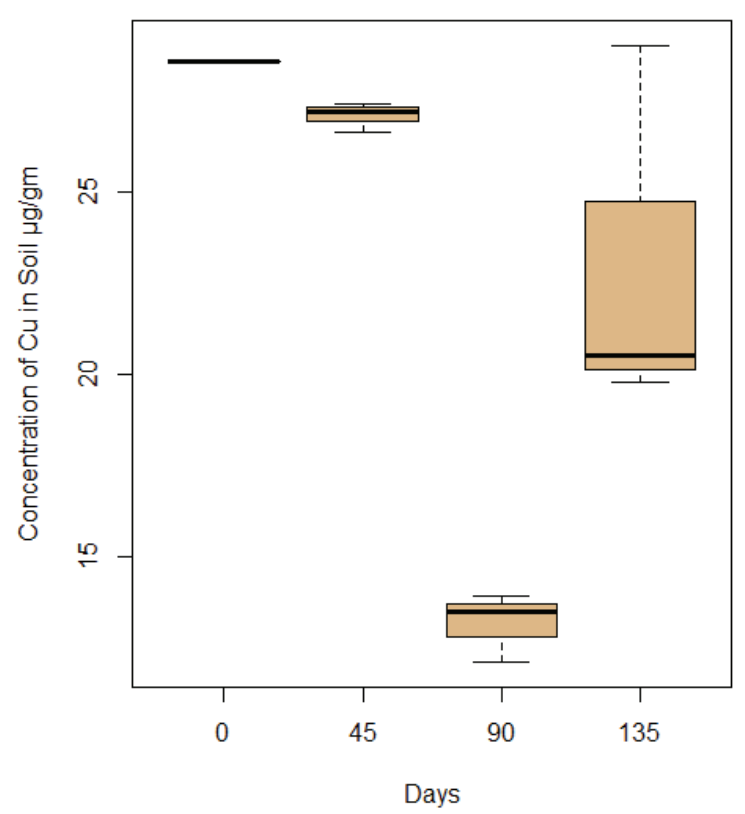

Concentration of $\mathrm{Cu}$ in Stem

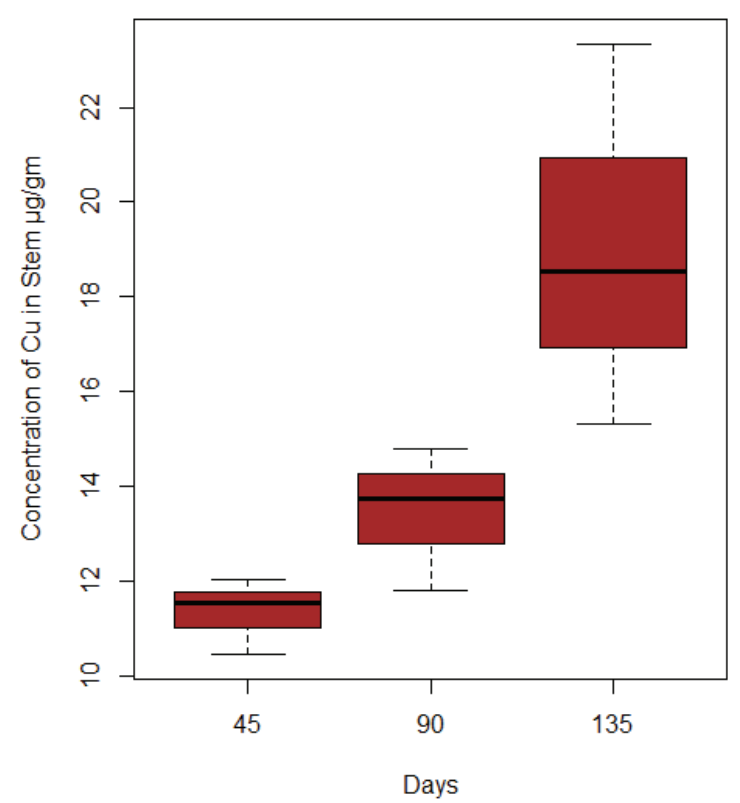

Concentration of $\mathrm{Zn}$ in Root

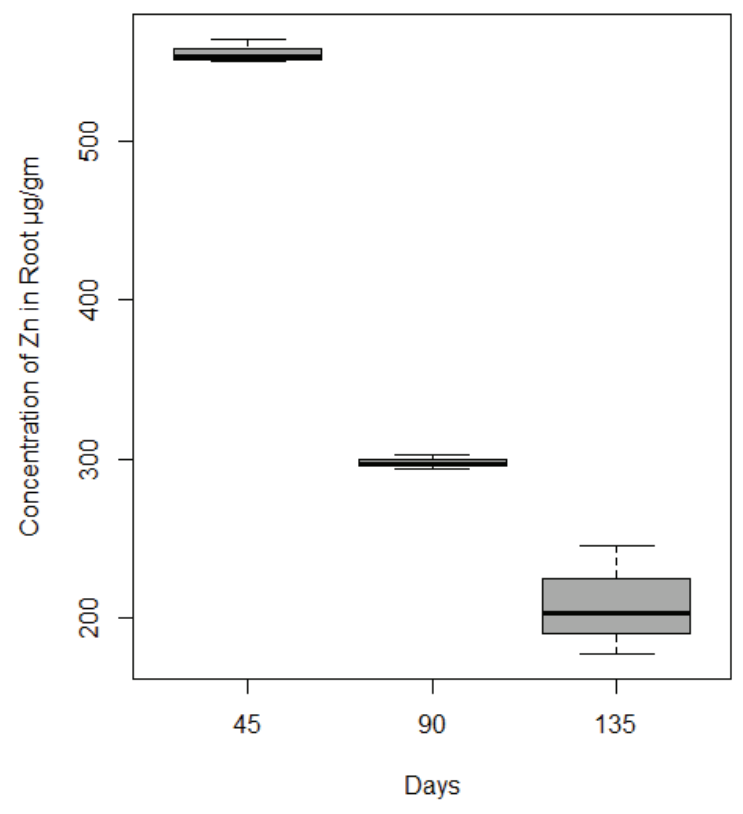

Concentration of $\mathrm{Cu}$ in Leaves

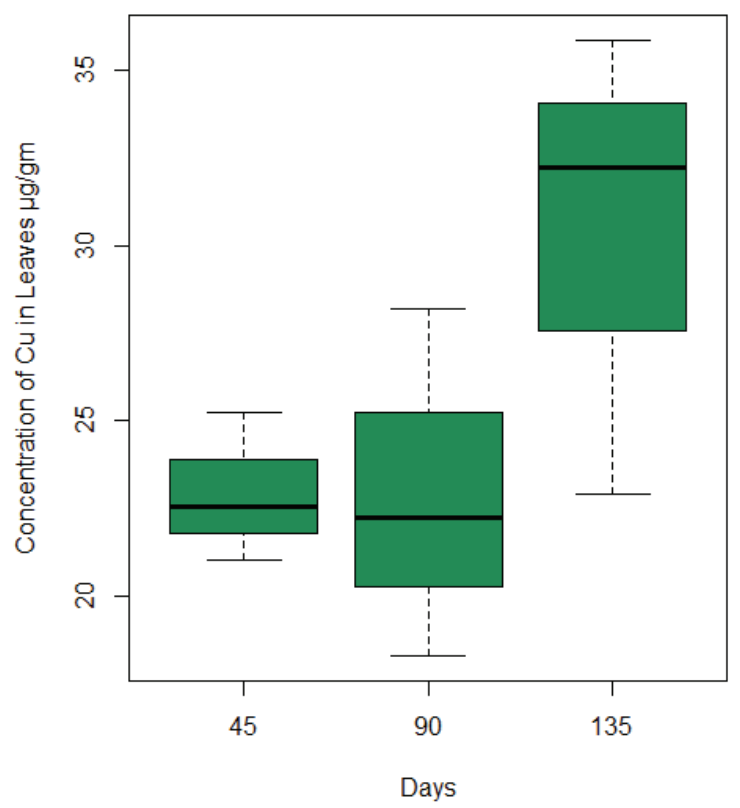

Figure 2. Concentration of Copper in contaminated soil, root, stem, and leaves at different intervals $(45,90,135$ days) 
mode as time passes by. On the other hand, the soil does not show sequential results regarding the $\mathrm{Cu}$ accumulation. Here, the other mechanisms might go on due to the soil-microorganism interaction besides the accumulation of metals by plants at different intervals of the experiment. Most soil animals, including protozoa, nematodes, collembola, mites, earthworms, etc. achieve their resources through the consumption of bacteria, fungi, or plant roots (Morris and Blackwood, 2015). For the removal of heavy metals, Ekwumemgbo et al. (2013), collected the soil samples from an industrial layout in Kano State, Nigeria, and analyzed for the total concentration of $\mathrm{Cd}, \mathrm{Cr}, \mathrm{Cu}, \mathrm{Ni}, \mathrm{Pb}$, $\mathrm{V}$, and $\mathrm{Zn}$. By applying Bryophyllum pinnatum for remediation of the above mentioned heavy metals and observed the reduction of heavy metals due to phytoextraction. In their study, the total uptake by plants might be expressed in the sequence of $\mathrm{Zn}>\mathrm{Pb}>\mathrm{Co}$. The uptake of metals by different parts of the plant showed a direction of leaves $>$ stems $>$ roots that might be established by that study (Ekwumemgbo et al., 2013). According to ANOVA analysis at $(\mathrm{p}<0.05)$ significance level, the concentration of $\mathrm{Cu}$ in soil, root, and stem of the Bryophyllum pinnatum plant showed significant variation in the present study. Conversely, the concentration value of $\mathrm{Cu}$ in leaves did not show such variation.

\section{Uptake of Zinc by Bryophyllum pinnatum from soil}

Figure 3 indicates that the concentration of $\mathrm{Zn}$ $(\mu \mathrm{g} / \mathrm{g})$ in the root of plant Bryophyllum pinnatum tends to decrease with time. However, the leaves tend to show the accumulation of $\mathrm{Zn}$ in the increasing mode for the time passes by; and the stem also tends to do so with the slight decreasing mode in the last observation of 135 days. In the case of the soil, the concentration of $\mathrm{Zn}$ in soil was decreased at 45 days (average $103.09 \mu \mathrm{g} / \mathrm{g}$ ) and then remained almost the same for other replications. Olegario et al., (2010) showed that the reduction or oxidation of metal occurred by microorganisms directly or by the reducing/oxidizing agents generated by those organisms. Redox reactions decrease the phytotoxicity of heavy metals by converting the mobile, toxic metals into non-mobile, non-toxic forms (Ma et al., 2016). According to ANOVA analysis at $(p<0.05)$ significance level, the concentration of $\mathrm{Zn}$ in the root, and leaves of plant Bryophyllum pinnatum showed significant variation. However, the concentration of $\mathrm{Zn}$ in soil and stem did not show such variation. The roots take up metals by two processes known as symplastic transport or by apoplastic transport (Ling et al., 2017; Thakur et al., 2016). Furthermore, the texture of the soil is regarded as an important criterion for the phytoavailability of heavy metals and finally for the efficacy of phytoextraction (Antoniadis et al., 2017; Liu et al., 2018).

Table 4. Distribution of $\mathrm{Cu}$ in soil, root, stem, and leaf of Bryophyllum pinnatum

\begin{tabular}{|c|c|c|c|c|c|c|c|c|}
\hline \multirow{2}{*}{ SI. No. } & \multirow{2}{*}{ Period in days } & \multirow{2}{*}{ Sample ID } & \multicolumn{3}{|c|}{ Cu Concentration $(\mu \mathrm{g} / \mathrm{g})$} & \multicolumn{3}{|c|}{ Accumulation factor } \\
\hline & & & soil & root & stem & leaves & ${ }^{*} \mathrm{BCF}$ & *TF \\
\hline \multicolumn{9}{|c|}{ Replica-1 } \\
\hline 01 & 45 & $\mathrm{~S}_{3}$ & 27.40 & 92.33 & 12.01 & 25.25 & 3.37 & 0.40 \\
\hline 02 & 90 & $\mathrm{~S}_{4}$ & 13.92 & 28.64 & 11.79 & 28.19 & 2.06 & 1.39 \\
\hline 03 & 135 & $\mathrm{~S}_{5}$ & 20.53 & 20.48 & 15.30 & 22.90 & 0.71 & 1.86 \\
\hline \multicolumn{9}{|c|}{ Replica-2 } \\
\hline 04 & 45 & $\mathrm{~S}_{3}$ & 26.63 & 53.62 & 10.45 & 21.04 & 2.01 & 0.59 \\
\hline 05 & 90 & $\mathrm{~S}_{4}$ & 12.14 & 36.23 & 14.78 & 18.29 & 2.98 & 0.91 \\
\hline 06 & 135 & $\mathrm{~S}_{5}$ & 19.78 & 22.76 & 23.34 & 35.87 & 1.15 & 2.60 \\
\hline \multicolumn{9}{|c|}{ Replica-3 } \\
\hline 07 & 45 & $\mathrm{~S}_{3}$ & 27.2 & 75.26 & 11.53 & 22.53 & 2.77 & 0.45 \\
\hline 08 & 90 & $\mathrm{~S}_{4}$ & 13.5 & 32.63 & 13.75 & 22.25 & 2.42 & 1.10 \\
\hline 09 & 135 & $\mathrm{~S}_{5}$ & 20.5 & 22.52 & 18.52 & 32.23 & 1.09 & 2.25 \\
\hline
\end{tabular}

Note: $\mathrm{S}_{3}-$ plant from contaminated soil (after 45 days); $\mathrm{S}_{4}-$ plant from contaminated soil (after 90 days); $\mathrm{S}_{5}-$ plant from contaminated soil (after 135 days).

*BCF, Bioconcentration Factor - metal concentration ratio of plant roots to soil (Herlina et al., 2020; Yoon et al., 2006) *TF, Translocation Factor - metal concentration ratio of plant shoots to roots(Herlina et al., 2020; Yoon et al., 2006). 
Concentration of $\mathrm{Zn}$ in Contaminated Soil

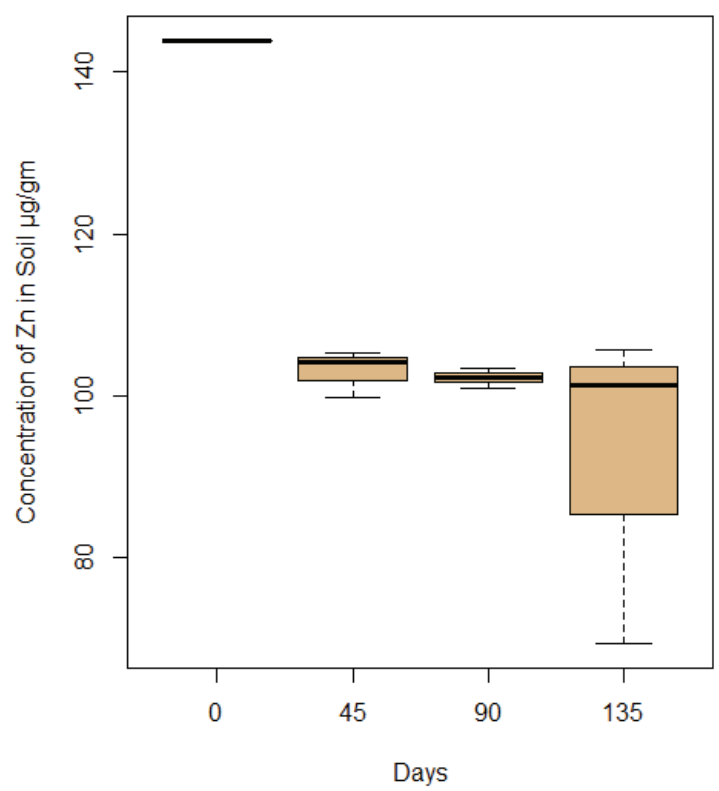

Concentration of $\mathrm{Zn}$ in Stem

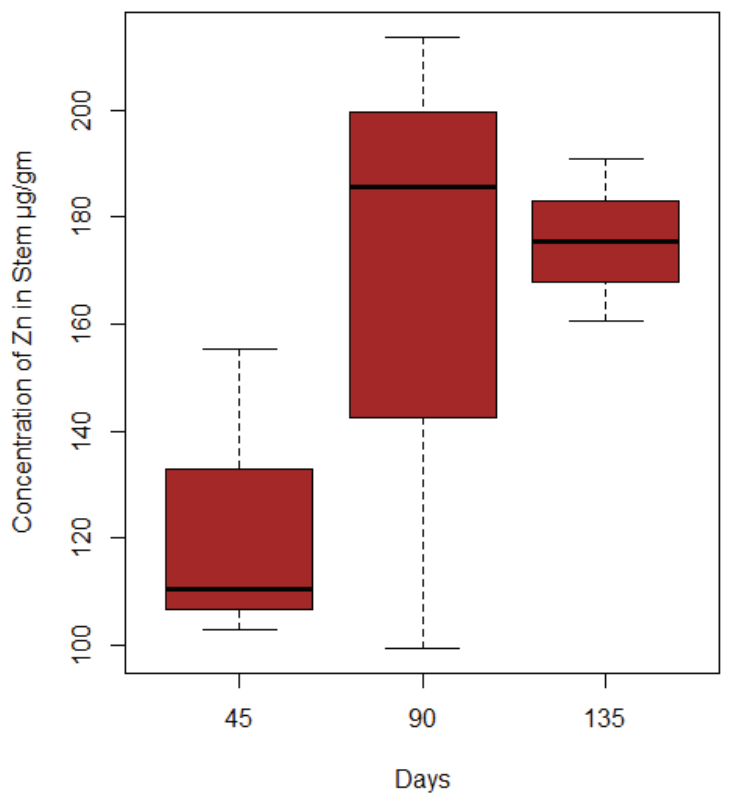

Concentration of $\mathrm{Zn}$ in Root

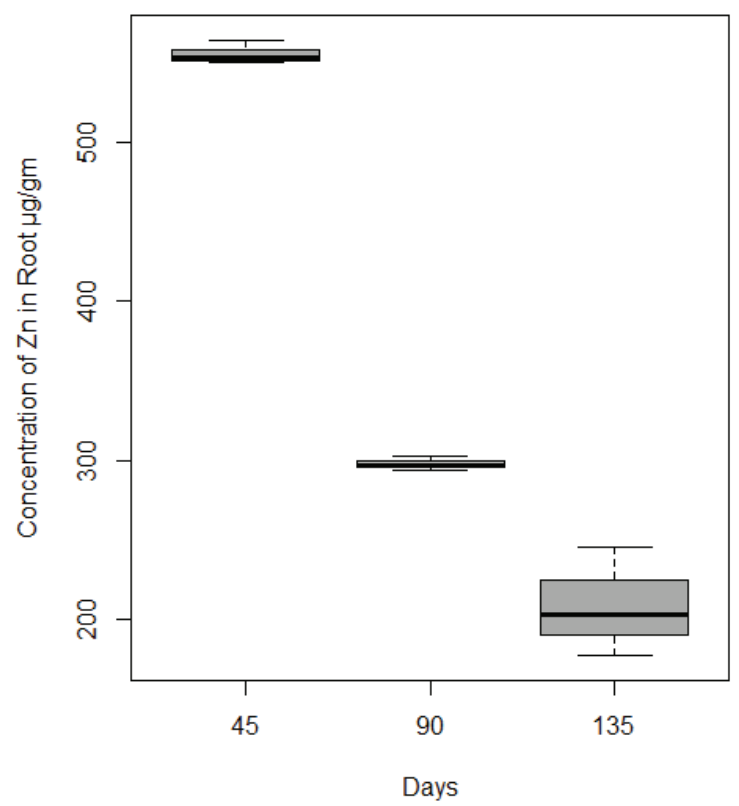

Concentration of $\mathrm{Cu}$ in Leaves

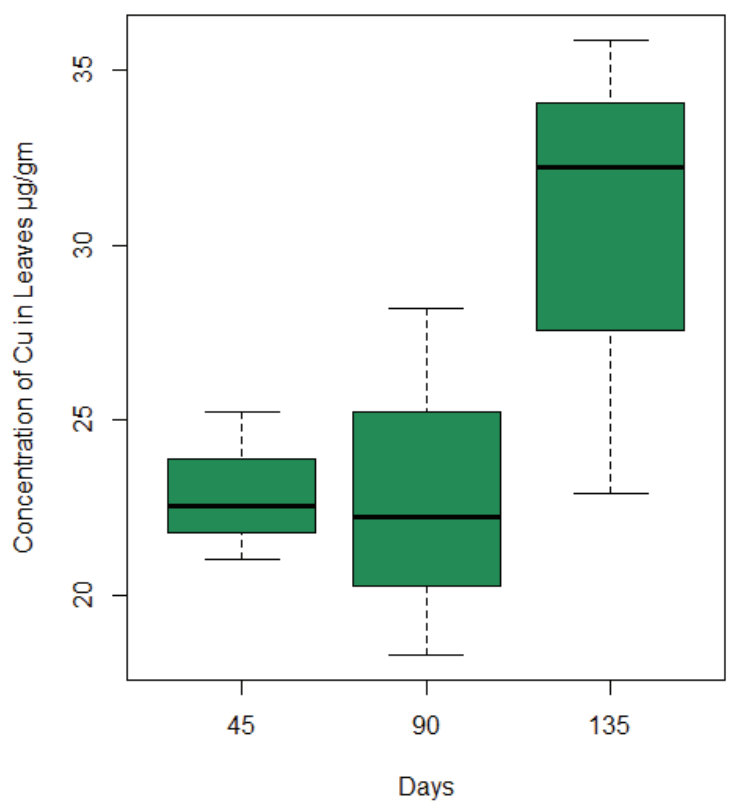

Figure 3. Concentration of Zinc in contaminated soil, root, stem, and leaves at different intervals $(45,90,135$ days)

\section{Bioaccumulation and Translocation factor of Bryophyllum pinnatum for $\mathrm{Cu}$ and $\mathrm{Zn}$}

The bioconcentration factor of Bryophyllum pinnatum for $\mathrm{Cu}$ tends to show a decreasing trend with the passage of time maintaining the sequence 45 days $>90$ days $>135$ days. However, the translocation factor of Bryophyllum pinnatum for $\mathrm{Cu}$ tends to show an increasing trend with the passage of time maintaining the sequence of 45 days $<90$ days $<135$ days. Bioconcentration factor (BCF) was calculated as the metal concentration in root divided by the metal concentration in the soil; translocation factor (TF) was calculated as the metal concentration in shoots divided by the concentration in roots (Herlina et al., 2020; Yoon et al., 2006). Again, the bioconcentration factor of Bryophyllum pinnatum for $\mathrm{Zn}$ tends to decrease with the passage of time maintaining the sequence 45 days $>90$ days $>135$ days. Likewise, Yang et al., 
Table 5. Distribution of $\mathrm{Zn}$ in soil, root, stem, and leaf of Bryophyllum pinnatum

\begin{tabular}{|c|c|c|c|c|c|c|c|c|}
\hline \multirow{2}{*}{ SI. No } & \multirow{2}{*}{ Period (days) } & \multirow{2}{*}{ Sample ID } & \multicolumn{4}{|c|}{ Zn concentration $(\mu \mathrm{g} / \mathrm{g})$} & \multicolumn{2}{|c|}{ Accumulation factor } \\
\hline & & & soil & root & stem & leaves & ${ }^{*} \mathrm{BCF}$ & ${ }^{*} \mathrm{TF}$ \\
\hline \multicolumn{9}{|c|}{ Replica-1 } \\
\hline 01 & 45 & $\mathrm{~S}_{3}$ & 105.27 & 563.83 & 155.25 & 220.13 & 5.36 & 0.67 \\
\hline 02 & 90 & $\mathrm{~S}_{4}$ & 103.45 & 302.99 & 99.40 & 261.28 & 1.41 & 1.19 \\
\hline 03 & 135 & $\mathrm{~S}_{5}$ & 69.47 & 177.65 & 190.91 & 250.73 & 2.55 & 2.49 \\
\hline \multicolumn{9}{|c|}{ Replica-2 } \\
\hline 04 & 45 & $\mathrm{~S}_{3}$ & 99.78 & 549.45 & 102.80 & 180.49 & 5.51 & 0.52 \\
\hline 05 & 90 & $\mathrm{~S}_{4}$ & 101.02 & 293.95 & 213.62 & 233.41 & 2.91 & 1.52 \\
\hline 06 & 135 & $\mathrm{~S}_{5}$ & 105.79 & 245.80 & 160.44 & 271.55 & 2.32 & 1.76 \\
\hline \multicolumn{9}{|c|}{ Replica-3 } \\
\hline 07 & 45 & $\mathrm{~S}_{3}$ & 104.23 & 552.58 & 110.50 & 205.23 & 5.30 & 0.57 \\
\hline 08 & 90 & $\mathrm{~S}_{4}$ & 102.25 & 296.87 & 185.52 & 240.25 & 2.90 & 1.43 \\
\hline 09 & 135 & $\mathrm{~S}_{5}$ & 101.36 & 202.98 & 175.36 & 280.52 & 2.00 & 2.25 \\
\hline
\end{tabular}

Note: $\mathrm{S}_{3}$ - plant from contaminated soil (after 45 days); $\mathrm{S}_{4}-$ plant from contaminated soil (after 90 days); $\mathrm{S}_{5}-$ plant from contaminated soil (after 135 days).

"BCF, Bioconcentration Factor - metal concentration ratio of plant roots to soil (Herlina et al., 2020; Yoon et al., 2006) *TF, Translocation Factor - metal concentration ratio of plant shoots to roots(Herlina et al., 2020; Yoon et al., 2006).

(2020) showed that the concentrations of $\mathrm{Zn}$ remained much higher in roots than in shoots. However, the translocation factor of Bryophyllum pinnatum for $\mathrm{Cu}$ tends to increase with the passage of time maintaining the sequence of 45 days $<90$ days $<135$ days. The study of Shi et al., (2016) identified that the two species, i.e. $R$. chinensis and $L$. formosana had noticeably higher translocation factor values for $\mathrm{Pb}(0.88)$ and $\mathrm{Zn}$ (1.78). The present study reveals a similar higher TF of Bryophyllum pinnatum for $\mathrm{Zn}$ (TF average 1.5; having a range from 0.52 to 2.49 ) and for $\mathrm{Cu}$ (TF average 1.28; having a range from 0.40 to 2.6). Therefore, this Bryophyllum pinnatum can be regarded as a hyperaccumulator plant $(\mathrm{BCF}>1)$ with better phytoextraction capacity because of the transfer of the metal to the stem and leaves from the roots over time. A translocation factor greater than 1 specifies favored segregating of metals to the shoots (Branquinho et al., 2007). On the other hand, the plants revealing $\mathrm{TF}$ and specifically $\mathrm{BCF}$ values less than one are unsuitable for phytoextraction (Fitz and Wenzel, 2002). Hypraccumulator plants take up toxic heavy metals in the tissues of the aboveground part of the plant, whereas non-hyperaccumulators receive the metals in the below-ground plant tissues (Sharma et al., 2016).

\section{CONCLUSIONS}

The presence of two heavy metals, i.e. $\mathrm{Cu}$ and $\mathrm{Zn}$, was observed in the contaminated soil around the textile industries at Kaliakair, Gazipur, Bangladesh. The other metals $\mathrm{Cd}, \mathrm{Cr}, \mathrm{Pb}$, and $\mathrm{Ni}$ were not found in that tested soil. The fresh plants initially possess some heavy metals because of the availability of metals in the contaminated soil. The plants extract these metals from the soil as nutrients. As Bryophyllum pinnatum is generally a non-edible plant, there is less chance of transfer of heavy metal to the human being through the food chain. The amount of heavy metals in the contaminated soil tends to be decreased over time after the planting of Bryophyllum pinnatum. Thus, this plant acts like a hyper-accumulator. Initially, the root takes up more metals than the stem and leaves of the plants, but when time goes on gradually, the stem and leaves accumulate more metals compared to the root. It can be decided that when the plants finish the growing stage, they are not likely to store nutrients in their root. Therefore, Bryophyllum pinnatum can be safely used as a phytoremediator.

\section{REFERENCES}

1. Alaboudi, K.A., Ahmed, B., Brodie, G., 2018. Phytoremediation of $\mathrm{Pb}$ and $\mathrm{Cd}$ contaminated soils by using sunflower (Helianthus annuus) plant. Ann. Agric. Sci. 63, 123-127. https://doi.org/10.1016/j. aoas.2018.05.007

2. Antoniadis, V., Levizou, E., Shaheen, S.M., Ok, Y.S., Sebastian, A., Baum, C., Prasad, M.N.V., Wenzel, W.W., Rinklebe, J., 2017. Trace elements in the soil-plant interface: Phytoavailability, translocation, 
and phytoremediation-A review. Earth-Science Rev. 171, 621-645. https://doi.org/10.1016/j. earscirev.2017.06.005

3. Branquinho, C., Serrano, H.C., Pinto, M.J., MartinsLoução, M.A., 2007. Revisiting the plant hyperaccumulation criteria to rare plants and earth abundant elements. Environ. Pollut. 146, 437-443. https://doi. org/10.1016/j.envpol.2006.06.034

4. Cambier, P., Pot, V., Mercier, V., Michaud, A., Benoit, P., Revallier, A., Houot, S., 2014. Impact of long-term organic residue recycling in agriculture on soil solution composition and trace metal leaching in soils. Sci. Total Environ. 499, 560-573. https://doi.org/10.1016/j.scitotenv.2014.06.105

5. Chehregani, A., Noori, M., Yazdi, H.L., 2009. Phytoremediation of heavy-metal-polluted soils: Screening for new accumulator plants in Angouran mine (Iran) and evaluation of removal ability. Ecotoxicol. Environ. Saf. 72, 1349-1353. https://doi. org/10.1016/j.ecoenv.2009.02.012

6. Chen, L., Luo, S., Li, X., Wan, Y., Chen, J., Liu, C., 2014. Interaction of Cd-hyperaccumulator Solanum nigrum L. and functional endophyte Pseudomonas sp. Lk9 on soil heavy metals uptake. Soil Biol. Biochem. 68, 300-308. https://doi.org/10.1016/j. soilbio.2013.10.021

7. Dubey, S., Shri, M., Gupta, A., Rani, V., Chakrabarty, D., 2018. Toxicity and detoxification of heavy metals during plant growth and metabolism. Environ. Chem. Lett. 16, 1169-1192. https://doi. org/10.1007/s10311-018-0741-8

8. Ekwumemgbo, P.A., Eddy, N.O., Omoniyi, I.K., 2013. Decontamination of heavy metals in polluted soil by phytoremediation using bryophyllum pinnatum. E3S Web Conf. 1, 1-4. https://doi.org/10.1051/ e3sconf $/ 20130113004$

9. Fitz, W.J., Wenzel, W.W., 2002. Arsenic transformations in the soil-rhizosphere-plant system: Fundamentals and potential application to phytoremediation. J. Biotechnol. 99, 259-278. https://doi. org/10.1016/S0168-1656(02)00218-3

10. Goswami, S., Das, S., 2016. Copper phytoremediation potential of Calandula officinalis L. and the role of antioxidant enzymes in metal tolerance. Ecotoxicol. Environ. Saf. 126, 211-218. https://doi. org/10.1016/j.ecoenv.2015.12.030

11. Gupta, A., Balomajumder, C., 2015. Phytoremediation of heavy metals and its mechanism: A brief review. J. Integr. Sci. Technol. 3, 51-59.

12. Herlina, L., Widianarko, B., Purnaweni, H., Sudarno, S., Sunoko, H.R., 2020. Phytoremediation of lead contaminated soil using croton (Cordiaeumvariegatum) plants. J. Ecol. Eng. 21, 107-113. https:// doi.org/10.12911/22998993/122238

13. Islam, M.S., 2012. Investigation of soil quality and heavy metal concentrations from a waste dumping site of Konabari industrial area at Gazipur in Bangladesh. IOSR J. Environ. Sci. Toxicol. Food Technol. 2, 01-07. https://doi.org/10.9790/2402-0210107

14. Jain, R.K., Kapur, M., Labana, S., Lal, B., Sarma, P.M., Bhattacharya, D., Thakur, I.S., 2005. Microbial diversity: application of microorganisms for the biodegradation of xenobiotics. Curr. Sci. 89, 101-112.

15. Kader, M., Lamb, D.T., Megharaj, M., Naidu, R., 2016. Sorption parameters as a predictor of arsenic phytotoxicity in Australian soils. Geoderma 265, 103-110. https://doi.org/10.1016/j. geoderma.2015.11.019

16. Kumar, S., Prasad, S., Yadav, K.K., Shrivastava, M., Gupta, N., Nagar, S., Bach, Q.V., Kamyab, H., Khan, S.A., Yadav, S., Malav, L.C., 2019. Hazardous heavy metals contamination of vegetables and food chain: Role of sustainable remediation approaches - A review. Environ. Res. 179, 108792. https://doi.org/10.1016/j.envres.2019.108792

17. Li, C., Zhang, Z., Li, Y., Cao, J., 2015. Study on dyeing wastewater treatment at high temperature by MBBR and the thermotolerant mechanism based on its microbial analysis. Process Biochem. 50, 1934-1941. https://doi.org/10.1016/j. procbio.2015.08.007

18. Ling, T., Gao, Q., Du, H., Zhao, Q., Ren, J., 2017. Growing, physiological responses and $\mathrm{Cd}$ uptake of Corn (Zea mays L.) under different Cd supply. Chem. Speciat. Bioavailab. 29, 216-221. https://doi. org/10.1080/09542299.2017.1400924

19. Liu, L., Li, W., Song, W., Guo, M., 2018. Remediation techniques for heavy metal-contaminated soils: Principles and applicability. Sci. Total Environ. 633, 206-219. https://doi.org/10.1016/j. scitotenv.2018.03.161

20. Ma, Y., Rajkumar, M., Zhang, C., Freitas, H., 2016. Beneficial role of bacterial endophytes in heavy metal phytoremediation. J. Environ. Manage. 174, 1425. https://doi.org/10.1016/j.jenvman.2016.02.047

21. Mani, S., Chowdhary, P., Hare, V., 2019. Industrial effluents: impact on agricultural soils and microbial diversity, in: Ajit Varma, Swati Tripathi, R.P. (Ed.), Plant Biotic Interactions. Springer Nature Switzerland AG, pp. 43-60.

22. Mao, X., Jiang, R., Xiao, W., Yu, J., 2015. Use of surfactants for the remediation of contaminated soils: A review. J. Hazard. Mater. 285, 419-435. https://doi.org/10.1016/j.jhazmat.2014.12.009

23. Morris, S.J., Blackwood, C.B., 2015. The Ecology of the Soil Biota and their Function, in: Paul, E.A. (Ed.), Soil Microbiology, Ecology and Biochemistry. Elsevier Inc., pp. 273-309. https://doi. org/10.1016/b978-0-12-415955-6.00010-4

24. Muthusaravanan, S., Sivarajasekar, N., Vivek, J.S., Paramasivan, T., Naushad, M., Prakashmaran, J., Gayathri, V.,Al-Duaij, O.K., 2018. Phytoremediation 
of heavy metals: mechanisms, methods and enhancements. Environ. Chem. Lett. 16, 1339-1359. https://doi.org/10.1007/s10311-018-0762-3

25. Nagajyoti, P.., Lee, K.., Sreekanth, T.., 2010. Heavy metals occurrence and toxicity for plants: a review. Environ. Chem. Lett. 8, 199-216.

26. Olegario, J.T., Yee, N., Miller, M., Sczepaniak, J., Manning, B., 2010. Reduction of Se(VI) to Se(II) by zerovalent iron nanoparticle suspensions. J. Nanoparticle Res. 12, 2057-2068. https://doi. org/10.1007/s11051-009-9764-1

27. Patra, D.K., Pradhan, C., Patra, H.K., 2020. Toxic metal decontamination by phytoremediation approach: Concept, challenges, opportunities and future perspectives. Environ. Technol. Innov. 18, 100672. https://doi.org/10.1016/j.eti.2020.100672

28. Phaenark, C., Pokethitiyook, P., Kruatrachue, M., Ngernsansaruay, C., 2009. Cd and Zn accumulation in plants from the Padaeng zinc mine area. Int. J. Phytoremediation 11, 479-495. https://doi. org/10.1080/15226510802656243

29. Pinto, A.P., Varennes, A. de, Fonseca, R., Teixeira, D.M., 2015. Phytoremediation of Soils Contaminated with Heavy Metals: Techniques and Strategies, in: Abid A. Ansari, Gill, S.S., Gill, R., Lanza, G.R., Newman, L. (Eds.), Phytoremediation: Management of Environmental Contaminants. Springer International Publishing, pp. 133-147. https://doi. org/10.1007/978-3-319-10395-2

30. Prasad, M.N.V., De Oliveira Freitas, H.M., 2003. Metal hyperaccumulation in plants - Biodiversity prospecting forphytoremediation technology. Electron. J. Biotechnol. 6, 110-146. https://doi. org/10.2225/vol6-issue3-fulltext-6

31. Sabir, M., Waraich, E.A., Hakeem, K.R., Öztürk, M., Ahmad, H.R., Shahid, M., 2015. Phytoremediation: Mechanisms and Adaptations. Mechanisms and Adaptations. Soil Remediat. Plants Prospect. Challenges 85-105. https://doi.org/10.1016/ B978-0-12-799937-1.00004-8

32. Shah, V., Daverey, A., 2020. Phytoremediation: A multidisciplinary approach to clean up heavy metal contaminated soil. Environ. Technol. Innov. 18, 100774. https://doi.org/10.1016/j.eti.2020.100774

33. Shaheen, S.M., Tsadilas, C.D., Rinklebe, J., 2013. A review of the distribution coefficients of trace elements in soils: Influence of sorption system, element characteristics, and soil colloidal properties. Adv. Colloid Interface Sci. 201-202, 43-56. https://doi. org/10.1016/j.cis.2013.10.005

34. Sharma, S.S., Dietz, K.J., Mimura, T., 2016. Vacuolar compartmentalization as indispensable component of heavy metal detoxification in plants. Plant Cell Environ. 39, 1112-1126. https://doi. org/10.1111/pce. 12706

35. Sherene, T., 2010. Mobility and transport of heavy metals in polluted soil environment.
Biol. Forum - An Int. J. 2, 112-121. https://doi. org/10.1097/00006454-199809000-00028

36. Shi, X., Chen, Y.T., Wang, S.F., Pan, H.W., Sun, H.J., Liu, C.X., Liu, J.F., Jiang, Z.P., 2016. Phytoremediation potential of transplanted bare-root seedlings of trees for lead/zinc and copper mine tailings. Int. J. Phytoremediation 18, 1155-1163. https://doi. org/10.1080/15226514.2016.1189399

37. Srivastava, N., 2016. Role of Phytochelatins in Phytoremediation of Heavy Metals Contaminated Soils. Phytoremediation Manag. Environ. Contam. Vol. 3 1-576. https://doi.org/10.1007/978-3-319-40148-5

38. Thakur, S., Singh, L., Wahid, Z.A., Siddiqui, M.F., Atnaw, S.M., Din, M.F.M., 2016. Plant-driven removal of heavy metals from soil: uptake, translocation, tolerance mechanism, challenges, and future perspectives. Environ. Monit. Assess. 188. https:// doi.org/10.1007/s10661-016-5211-9

39. Tusher, T., Piash, A., Latif, M., Kabir, M., Rana, M., 2018. Soil Quality and Heavy Metal Concentrations in Agricultural Lands around Dyeing, Glass and Textile Industries in Tangail District of Bangladesh. J. Environ. Sci. Nat. Resour. 10, 109-116. https://doi.org/10.3329/jesnr.v10i2.39020

40. Tusher, T., Piash, A., Latif, M., Kabir, M., Rana, M., 2017. Soil Quality and Heavy Metal Concentrations in Agricultural Lands around Dyeing, Glass and Textile Industries in Tangail District of Bangladesh. J. Environ. Sci. Nat. Rexources 10, 109-116.

41. Volk, J., Yerokun, O., 2016. Effect of application of increasing concentrations of contaminated water on the different fractions of $\mathrm{Cu}$ and $\mathrm{Co}$ in sandy loam and clay loam soils. Agriculture 6, 1-19. https://doi. org/10.3390/agriculture6040064

42. Wei, H., Huang, M., Quan, G., Zhang, J., Liu, Z., Ma, R., 2018. Turn bane into a boon: Application of invasive plant species to remedy soil cadmium contamination. Chemosphere 210, 1013-1020. https:// doi.org/10.1016/j.chemosphere.2018.07.129

43. Yang, W., Wang, Y., Liu, D., Hussain, B., Ding, Z., Zhao, F., Yang, X., 2020. Interactions between cadmium and zinc in uptake, accumulation and bioavailability for Salix integra with respect to phytoremediation. Int. J. Phytoremediation 22, 628-637. https://doi.org/10.1080/15226514.2019.1701981

44. Ye, S., Zeng, G., Wu, H., Zhang, Chang, Dai, J., Liang, J., Yu, J., Ren, X., Yi, H., Cheng, M., Zhang, Chen, 2017. Biological technologies for the remediation of co-contaminated soil. Crit. Rev. Biotechnol. 37, 1062-1076. https://doi.org/10.1080/07388 551.2017 .1304357

45. Yoon, J., Cao, X., Zhou, Q., Ma, L.Q., 2006. Accumulation of $\mathrm{Pb}, \mathrm{Cu}$, and $\mathrm{Zn}$ in native plants growing on a contaminated Florida site. Sci. Total Environ. 368, 456-464. https://doi.org/10.1016/j. scitotenv.2006.01.016 